Article

\title{
Waste Management in Green and Smart Cities: A Case Study of Russia
}

\author{
Zhanna Mingaleva ${ }^{1,2}$, Natalia Vukovic ${ }^{3,4, *}$, Irina Volkova ${ }^{5}$ and Tatiana Salimova ${ }^{6}$ \\ 1 Department of Economics and Industrial Production Management, Perm National Research Polytechnic \\ University, Perm 614990, Russia; mingal1@pstu.ru \\ 2 Department of Management, Perm State Agrarian and Technological University, Perm 614990, Russia \\ 3 Scientific Center of High-tech Systems Modeling and Info-communications, Peoples' Friendship University \\ of Russia (RUDN University), Moscow 117198, Russia \\ 4 Department of Economics, Saint-Petersburg State Forest Technical University, St Petersburg 194021, Russia \\ 5 Department of General and Strategic Management, National Research University Higher School of \\ Economics, Moscow 101000, Russia; iovolkova@hse.ru \\ 6 Department of Economics, National Research Mordovia State University, Saransk 430005, Russia; \\ t.a.salimova@econom.mrsu.ru \\ * Correspondence: VukovichNA@spbftu.ru
}

Received: 12 November 2019; Accepted: 12 December 2019; Published: 21 December 2019

\begin{abstract}
This article aims to investigate the role of waste management in the development of modern green and smart cities and to determine the existence of several key points in programs transforming cities into green cities with smart technologies. The relevance of the research is determined by the need to develop a theoretical and methodological basis for the green and smart city concepts. The research process involved the following methods: Scientific analysis, comparison, and synthesis. The research results of the case study of Russia determined that for urban territories with great distances between urban districts, waste sorting stations should be located as parts of so-called waste recycling complexes at intermunicipal landfills. This will allow a more fully implementation of the concept of recycling economy not only in Russian cities, but also in other cities with sparse populations across the world. Further, the authors conclude that the effectiveness of green technologies in modern cities, especially in waste management, depends on the level of participation of citizens. People are active participants in the life processes of cities and have a direct impact on the urban environment. Consequently, the introduction of green technologies can only be achieved in harmony with the well-established behavioral attitudes of city residents together with the implementation of green and smart urban technologies.
\end{abstract}

Keywords: green economy; green city; smart city; waste management; recycling

\section{Introduction}

The basic principles of green economy introduced by Burkart (2009) [1] have been implemented successfully in many countries across the world by many green city projects. We can consider individual specific cases from different countries. In Russia, for example, pertinent cases involve waste management and eco-transport (Vukovic, Pobedinsky, Mityagin, Drozhzhin, Mingaleva (2019)) [2]. Furthermore, the development of a green economy in Russia can improve existing industry imbalances resulting from traditional industries in country regions by formation of new sustainable industries (Eydenzon, Ganieva, Shpak (2013)) [3].

The smart city and green city concepts have much in common in terms of their origins and mutual influence on progress. Many scientists have investigated the green and smart city concepts together, 
such as Martin, Simon, Daan, Changie, and Margot (2015), as well as Soumya, Alok, Polzonetti, Sagratella, Donnellan, Klein, Helfert, Gusikhin, and Pascoal (2018) [4-7]. As presented in Table 1, almost all aspects of the concepts of green city and smart city have mutual interests. Therefore, as presented in Table 1, waste management is an important element in the concepts of both smart and green cities in order to solve problems such as adapting to climatic change in terms of intelligent security systems and protecting and conserving the urban ecosystem(Table 1).

Table 1. Common Elements of the Smart City and the Green City Concepts.

\begin{tabular}{|c|c|c|c|c|}
\hline \multirow{2}{*}{ Green City Sectors [1] } & \multicolumn{4}{|c|}{ Smart City Dimensions [8] } \\
\hline & City Governance & $\begin{array}{l}\text { Environ-Urban } \\
\text { Configuration }\end{array}$ & $\begin{array}{l}\text { Techno-Economic } \\
\text { Dynamics }\end{array}$ & $\begin{array}{l}\text { Socio-Institutional } \\
\text { Structure }\end{array}$ \\
\hline Renewable energy & \multirow{2}{*}{\multicolumn{4}{|c|}{$\begin{array}{c}\text { Adapting to climatic change in terms of intelligent security systems } \\
\text { Improving the quality and reliability of environmental assessments by using } \\
\text { digital technologies }\end{array}$}} \\
\hline Green buildings & & & & \\
\hline Susta & \multicolumn{4}{|c|}{ Improving the environmental situation by using digital technologies } \\
\hline Water management & \multicolumn{4}{|c|}{ Improving the efficiency of the use of natural resources } \\
\hline Waste management & \multicolumn{4}{|c|}{$\begin{array}{l}\text { 1. Adapting to climatic change in terms of intelligent security systems } \\
\text { 2. Protecting and conserving the urban ecosystem }\end{array}$} \\
\hline Land management & \multicolumn{4}{|c|}{$\begin{array}{c}\text { Reducing the dynamics and response time to emergency situations by using } \\
\text { digital technologies }\end{array}$} \\
\hline
\end{tabular}

It is important in investigations of green city development to measure green city performance and the recycling of waste management systems correctly, as is presented in the research of Brilhante and Klaas (2018) [9]. The analysis of experiences in the implementation and realization of the green city concept revealed the existence of the following key points in programs for transforming cities into green cities [1]:

- Clean air (the maximum reduction of atmospheric emissions; the use of eco-transport);

- Minimizing urban waste (creating a system for complete domestic and industrial waste disposal);

- Rational use of energy (energy saving and its production by use of alternative energy sources);

- Urban forests and gardens (creating green areas in the framework of housing density).

Decision making depends on the historical heritage (urban planning, industrial enterprises, building density, etc.) and existing conditions of the town, as well as which problem the citizens consider to be the most important. For example, for Chinese and Indian cities, an annual increase in carbon dioxide emissions produced by industrial enterprises and motor transport, as well as toxic gases from disposal tips, was the most important problem. Together, these emissions create large clouds of toxic smog over Chinese and Indian cities. People must wear medical face masks, suspend classes at schools, close leisure facilities, cancel flights, close roads, and impose many limits concerning vital activities in the cities because of this toxic smog. Sometimes, the concentration of harmful agents in the atmosphere of the cities exceeds deadly limits. According to the World Health Organization, at the beginning of 2017, the concentration of toxic smog in Beijing exceeded deadly limits by 24 times; this lasted for one week. In India in, October 2019, the concentration of toxic agents in the atmosphere of Delhi reached a mark of 900 , which is deadly (the normal concentration is 50 marks). There are many such examples, even in some Russian cities. The transition to the green cities concept requires a solution in terms of monitoring and improving the quality of urban air. That is why it is very important to determine the reasons behind atmospheric pollution in cities.

Traditionally, the main sources of air pollution are the following:

1) Industrial enterprises,

2) motor transport, and

3) recycling of domestic and industrial waste.

It is evident that two of the three sources are connected to the behavioral attitudes of city residents and urban culture. Therefore, it is not only a question of implementing green and smart technology in 
modern cities, but also a question of increasing the numbers of smart citizens in urban populations. As presented in Table 2, citizens generally have a strong influence on the implementation of the green and smart city concepts ( 15 of 25 elements or $60 \%$ of the structure)-in terms of waste management, specifically. Therefore, smart technology applications for the networking of smart citizens in the field of the green city concept are among the first priorities for urban development.

Table 2. Roles of Smart Citizens in the Implementation of the Smart City Concept.

\begin{tabular}{|c|c|c|}
\hline & Smart City Elements [1] & Direct Influence of Smart Citizens \\
\hline 1 & Funding and investments & \\
\hline 2 & Partnerships & V \\
\hline 3 & Dedicated organizations & $\mathrm{V}$ \\
\hline 4 & E-governance & \\
\hline 5 & Public services & \\
\hline 6 & Decision-making & V \\
\hline 7 & Strategic plan & \\
\hline 8 & Quadruple-helix approach & \\
\hline 9 & Actions/initiatives/projects & V \\
\hline 10 & Urban design & V \\
\hline 11 & Innovation districts & \\
\hline 12 & Living Labs Delimited & \\
\hline 13 & Mobility & V \\
\hline 14 & Amenities and facilities & \\
\hline 15 & Natural resources & $\mathrm{V}$ \\
\hline 16 & Spirit of community & $\mathrm{V}$ \\
\hline 17 & Smart citizens & $\mathrm{V}$ \\
\hline 18 & Social and cultural plurality & V \\
\hline 19 & Rule of law & \\
\hline 20 & Land use & V \\
\hline 21 & Economic activities & \\
\hline 22 & Human capital and entrepreneurship & V \\
\hline 23 & Research, education and technology & V \\
\hline 24 & Collaborative spaces & V \\
\hline 25 & Global business networks/internationalization & $\mathrm{V}$ \\
\hline
\end{tabular}

The Russian civilians need to be engaged in the development of a new waste management system, especially because nowadays, there are more than 60 thousand illegal landfill sites in Russia. It is evident that new waste management reform in Russia cannot succeed without the active participation of citizens. The problem of minimizing urban waste management in a Russian case study can be solving effectively by implementing both approaches in the development of the following:

- $\quad$ Networking of smart citizens in the projects of waste management;

- Creating new waste recycling technologies.

Due to the concept of the green city, the pollution sources can be different for different countries. Thus, for India, the sources of atmospheric emissions are seasonal. Such pollution, caused by the farmers who incinerate straw in the fields-together with the emissions from motor transport-leads to atmospheric and environmental degradation. For Chinese cities, motor transport emissions and emissions of industrial enterprises are the most dangerous.

Like with the case of the green economy, the national model of the green city and waste management as the part of the green city can vary between different countries. In some cases, the concept can be connected with the design process of integrated municipal waste management and energy recovery like in Argentina (Morero, Montagna, Campanella, and Cafaro (2020)) [10].

In other cases, the waste management is oriented towards rejected fractions of municipal solid waste as a source of refuse-derived fuel, as shown in the case study of Isfahan-Iran Shumal, Jahromi, Ferdowsi, Dehkordi, Moloudian, and Dehnavi (2020) [11]. In addition, it is oriented towards optimal planning of transportation of classified domestic garbage based on map distance, like in the articles of Lou, Shuai, Luo, and Li (2020) [12]. In the Russian case of smart city (Vukovic, Rzhavtsev, and 
Shmyrev (2019)) [13], waste management also can be a part of the alternative energy cluster because other alternative energy sources are not effective enough (Mingaleva, Shpak (2015)) [14].

For Russia, the main problem of sustainable development is generally connected with the quality of waste management (Salimova, Gouskova, Fedoskina, and Gorin) [15]. Many Russian cities, such as Chelyabinsk, Omsk, Kurgan, and some other cities, have faced serious problems. In the summer of 2019, the citizens of Omsk suffered from atmospheric emissions from the incineration of domestic and industrial waste; the same case happened in the Chelyabinsk region. The citizens of Kurgan suffer every year from the incineration of domestic waste in the suburbs. Further for urban waste management systems is important to forecast possible uncertainty in terms of weighing-machine automation and it is an important part of green and smart cities future. (Slanina, Pokorny, and Dedek (2018), Tirkolaee, Mahdavi, Esfahani, Weber, Weidner, and Yang (2020)) [16-18].

By the end of the year 2019, all housing stock in Kazan must apply only separate waste collection. The Bryansk region became the leader in the sphere of effective regional policy of reforming the system for solid domestic waste utilization. The pilot project of separate collection of waste started in Kamchatka. The new system for the use of solid domestic waste has been applied in Krasnogorsk city.

In Russian cities, the main pollution sources are motor transport emissions and incineration of domestic waste. We compared two Russian capitals and two Russian regional centers using the criteria of population density and solid waste per citizen, as is presented in Table 3. We chose the city of Perm for a case study of a Russian city for more detailed research, and as a model for a case study of Russia using the criterion of urban population density, because this city has more than 1 million citizens, is located between Asia and Europe, and, as is the usual case for Russia, has a sparse population; the Russian capitals, Moscow and Saint Petersburg, are not usual cases for Russia in terms of urban development. Perm is one of the leaders in developing the concept of green cities. Perm is a big city with a population of more than one million people. The city can be characterized by the rich historical heritage in the sphere of greening the city territories, which has been supported by the city government for more than 200 years, as well as the active efforts of regional and local authorities to implement the concept of green cities. Historically, Perm follows a kind of housing development in which residential areas are surrounded by forests and river valleys.

Table 3. Russian Cities and Population Density.

\begin{tabular}{lcccc}
\multicolumn{1}{c}{ Characteristics } & \multicolumn{3}{c}{ Russian Cities } \\
& Moscow & Saint-Petersburg & Saransk & Perm \\
\hline Population 2019, people & $12,615,882$ & $5,383,968$ & 318,578 & $1,053,938$ \\
Urban Square, sq.km & 2561 & 1439 & 81.5 & 801.44 \\
Population density, people per sq.km & 4926 & 3741 & 3909 & 1315 \\
\hline
\end{tabular}

Nowadays, forests and parks occupy practically half of the city territories (that is, more than 40,000 hectares). That is why Perm is recognized as one of the greenest municipalities of the country and received the title of "eco-polis".

According to its Greenpeace rating, Perm is among the top 10 Russian cities in separate collection of waste. Problems of waste utilization have been solved by regional authorities in recent years. It is important to point out that Perm citizens do not suffer from the incineration of domestic waste and industrial emissions, though Perm is an old industrial city with many industrial chemical, petrochemical, and pharmaceutical enterprises situated in the city's territory.

People notice unpleasant smells caused by the industrial emissions no more that 2-3 times per year. Perm and the Perm region have a high positive rating among Russian cities in the sphere of waste utilization.

Therefore, it will be interesting for other cities of the world how the city of Perm has developed the concept of a recycling economy in the framework of a green city on an industrial background. 


\section{Materials and Research Methods}

The concept of circular economy was used as the main methodological approach. It means that city residents first try to produce as little trash as possible, and then the waste is sorted and processed for reuse.

This concept sets the following basic parameters for creating a modern waste management system:

- Amount of waste generated by residents of the city and infrastructure entities;

- Waste structure and the possibility of their secondary use;

- Separate waste collection systems;

- Waste sorting stations for a more complete separation of garbage into separate fractions;

- Specialized plants (production at existing enterprises) for the recycling of specific types of garbage and secondary raw materials (paper waste, wood waste, textiles, glass, mercury-containing elements, used batteries, etc.);

- Integrated waste recycling plants, which provide for the recycling of various types of municipal solid waste (MSW) and the preparation of non-processed types for safe disposal;

- Transport accessibility of all settlements for timely garbage collection.

The concept of the recycling economy is used in this study to create a modern waste management system. It is complemented by classical methods of economic analysis and visualization of research results.

In the present work, we used a graphical method to construct a transport and logistics scheme for the placement of new types of landfills and for ensuring optimal loading of garbage transfer stations. In order to calculate the capacities of landfills and garbage transfer stations, the normative method for calculating the amount of MSW generation by settlements and the unit cost method for transporting waste before and after transshipment were used.

The normative method for calculating the capital and specific operating costs for the transfer of garbage was used to calculate the optimal number of landfills and waste transfer stations.

The graphical method was used to display the optimal layout of landfills and waste handling stations in the Perm Territory, which minimizes the total cost of waste transportation.

The territorial scheme of waste management—including municipal solid waste-of the Perm Territory was used as the main material for the study (this scheme was approved as a normative document by the Ministry of Construction, Housing, and Communal Services of the Perm District, dated December 9, 2016, No. SED-35-01-12-503). The data from municipal statistics on the number of inhabitants in specific settlements of the Perm Territory were used to determine the potential volume of production of municipal solid waste factory. The authors implemented the placement of new types of landfills, cartographic data of Geographic Information System and official statistics on the length of roads in the Perm District for analysis of the transport and logistics scheme.

\section{Research}

Research of world experience in waste management showed the presence of three main options for the disposal of municipal solid waste (MSW): Incineration, landfill, and recycling. The application of these options is directly dependent on and closely related to the waste collection procedure. Thus, during mass waste disposal at landfills, pre-sorting of waste is most often not used and the types of waste are all stored together, often increasing the negative emissions due to their combination. When incinerating waste, preliminary sorting of waste is required, since different types of materials require different conditions for incineration (combustion temperature, degree of gas purification from incineration, methods of ash utilization, etc.).

In addition, some types of waste should not be in the furnace at all, because they have a high degree of toxicity. When using the most complete method of recycling of MSW, careful preliminary sorting of garbage at special stations and factories is required. In Russia, there are three main ways of collecting solid domestic waste (see Figure 1). 


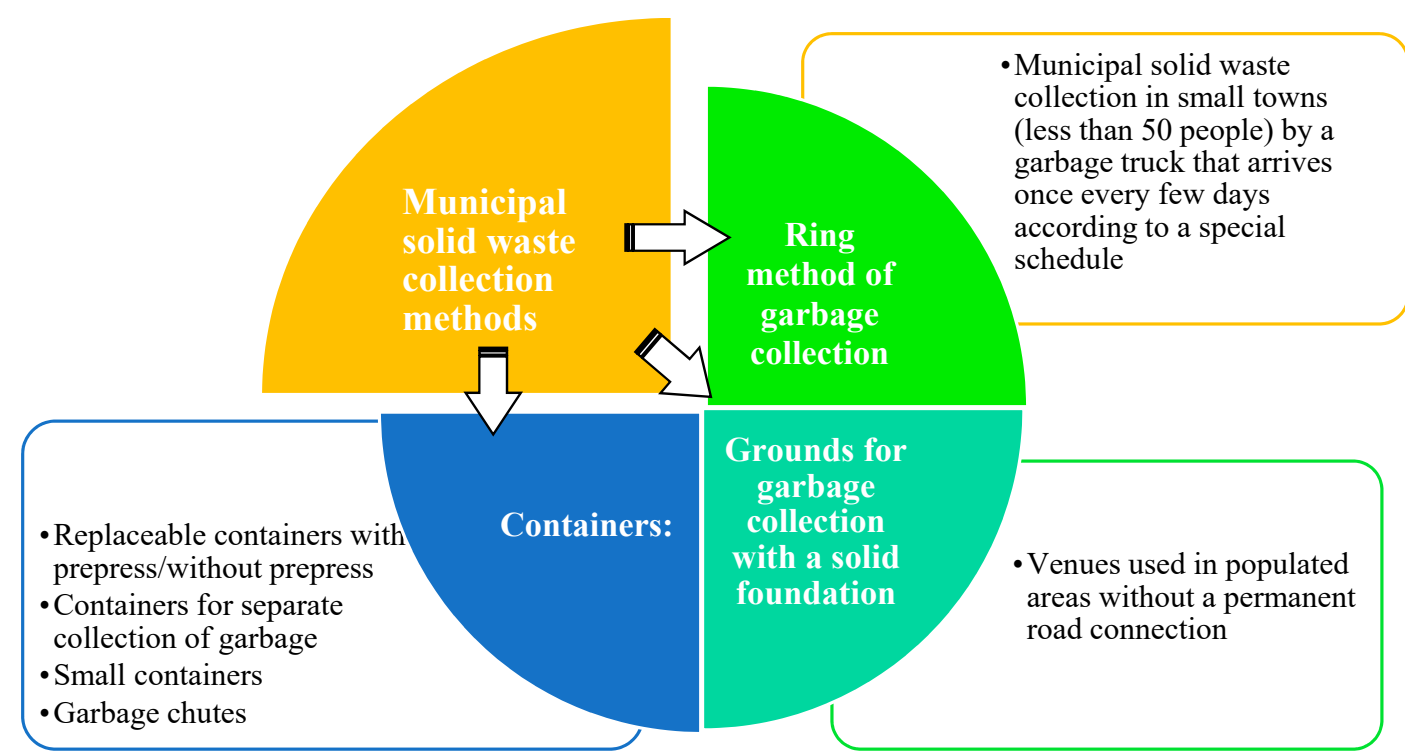

Figure 1. The main methods of municipal solid waste collection from the population and infrastructure in Russia. Source: Authors.

The three ways of collecting MSW presented in Figure 1 are provided through the use of six main technologies for accumulating MSW from the population and infrastructure. These technologies are used in Russian cities and municipalities depending on the volume of accumulated garbage and the possibilities of its removal (automobile accessibility to the village).

In general, the current MSW collection system in Russia has a number of drawbacks that accumulate as the volume of generated waste increases and the landfills are filled. These are the disadvantages of the existing MSW collection system:

1. Joint collection of all waste in one standard container (without lid) in municipalities and cities of Russia where separate waste collection is not yet widely used.

2. Incomplete coverage of waste sources by the waste collection system, which leads to unauthorized waste disposal in the environment (out of 711 MSW disposal facilities in the Perm region, 697 facilities were not authorized).

3. A high degree of deterioration of the container fleet and non-compliance of the placement and arrangement of container sites with the requirements of regulatory legislation.

4. Small garbage trucks for the collection and transportation of waste in most settlements, the efficiency of which decreases sharply when transporting waste over a distance of more than $5-10 \mathrm{~km}$.

5. A high degree of wear of much of the fleet of garbage trucks (in the Perm region, the wear of garbage trucks is more than $70 \%$ ), which requires their modernization.

6. Long distances from waste collection to landfills (in the Perm region, the average distance from waste removal to landfills is $35-40 \mathrm{~km}$, though the optimal transportation distance is $10 \mathrm{~km}$. The maximum distances for garbage removal exceed $100 \mathrm{~km}$ ).

7. A large number of small landfills that are not re-cultivated and actively pollute the environment (in the Perm region, only 72 out of 711 MSW accommodation sites have been re-cultivated).

Assessment of the situation of the collection and disposal of garbage in the Perm region showed the following. In the Perm region, all MSW collection technologies and two basic options for waste management (disposal and recycling) are used. Currently, the predominant method of waste management is waste disposal. According to the Ministry of Housing and Public Utilities, all of the garbage of Perm region residents is transported to 14 legal landfills, which are almost completely filled, 
and the technology for the disposal of waste is already very outdated. The current scheme for the placement and recycling of MSW is shown in Figure 2.

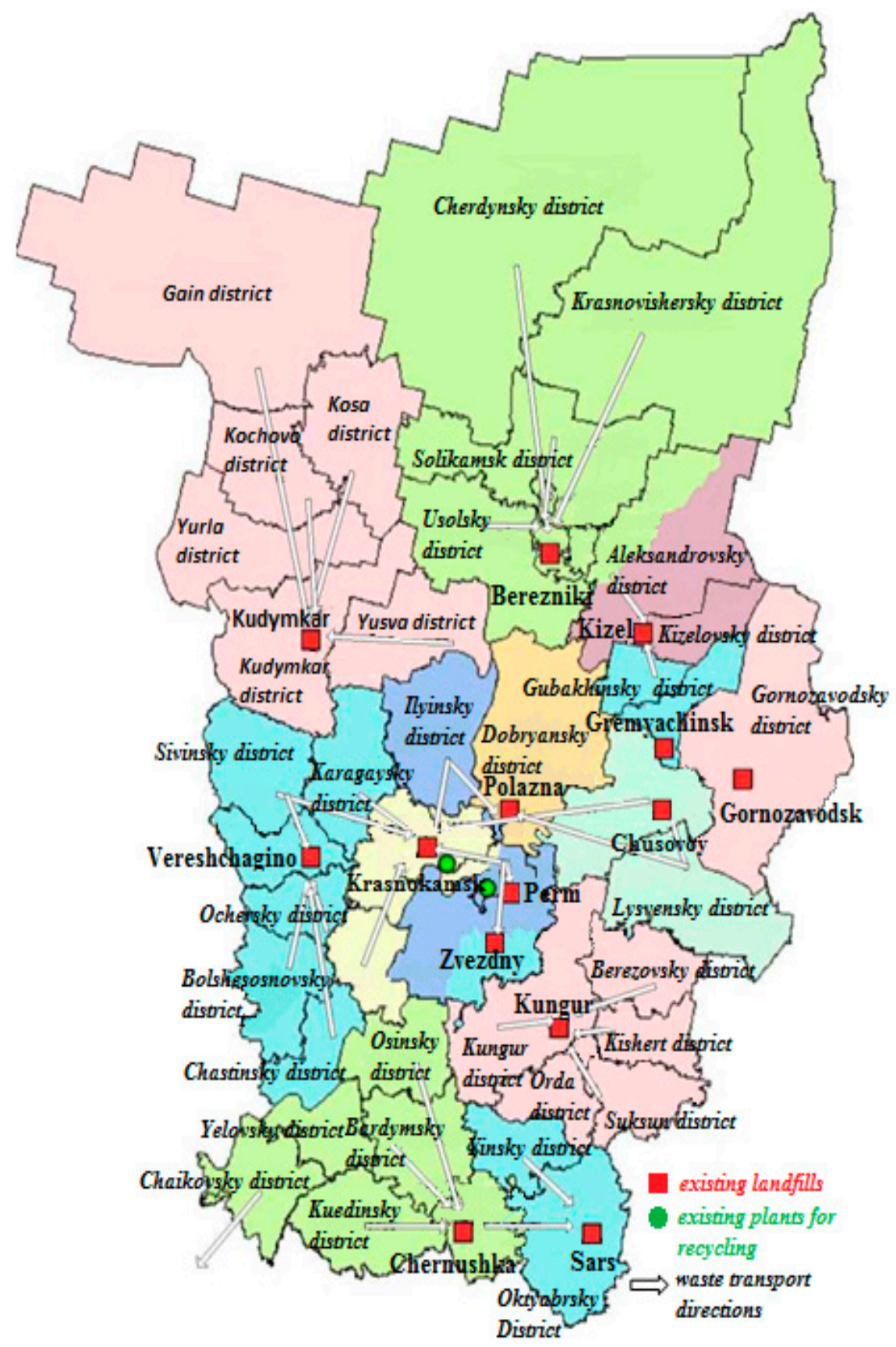

Figure 2. The current scheme for the placement and recycling of MSW in the Perm region. Source: https:/investinfra.ru/frontend/images/RO/59/Reformirovanie_sistemi_TKO_prezentacia.pdf.

MSW collection in the city of Perm is carried out according to the two-stage schemes; there are 2 waste transfer stations. In other cities and towns of Perm region, a one-stage waste collection scheme is used. In the Berezovsky, Kochevsky, Kudymkar and Yusvensky districts, waste is collected using temporary storage sites.

In addition, in the city of Perm and in a number of cities in Perm region, separate garbage collection has been organized, marshaling yards have been built, and modern waste disposal methods have been applied. However, the problem of household waste remains acute. This is due to the fact that the existing landfills for waste disposal are already almost completely filled, and the level of 
waste recycling is still low. In addition, the disposal system for landfills, which was formed more than 20 years ago, is not optimal.

The territorial waste management scheme developed at Perm National Research Polytechnic University in 2016 and which underlies the reform of the MSW management system in the Perm region provided for the construction of six waste recycling complexes by 2028. These complexes will consist of a sorting plant and a modern landfill for waste disposal. The cities of Perm, Berezniki, Lysva, and Tchaikovsky, as well as the Kungursky and Nytvensky municipal districts, were selected as the main centers for the placement of garbage recycling complexes. These six new complexes (marked in green in Figure 3) should complement the two existing waste recycling complexes in the city of Perm and the city of Krasnokamsk (marked in red in Figure 2).

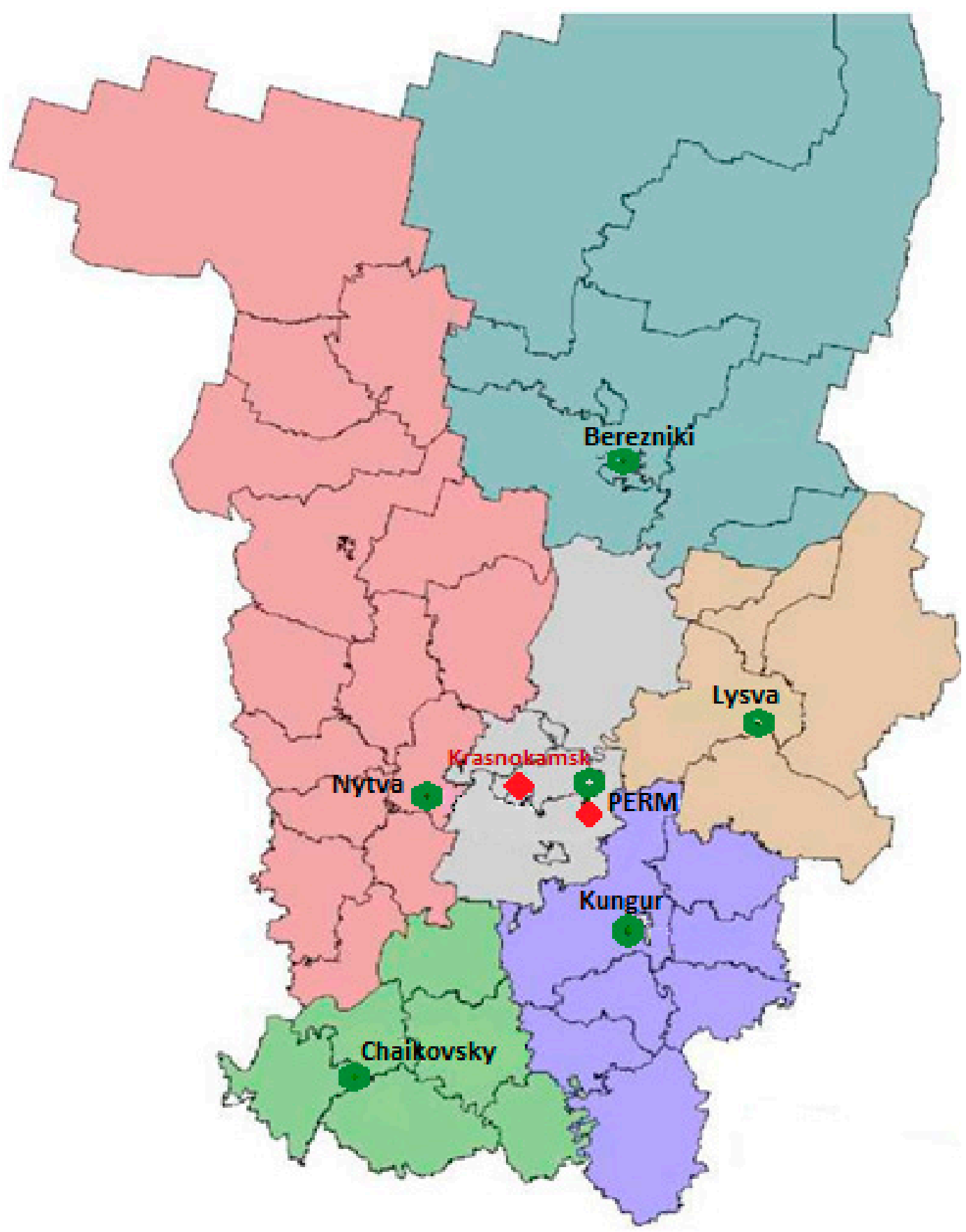

Figure 3. Design scheme for reforming the solid domestic waste management system in the Perm District. Source: https://investinfra.ru/frontend/images/RO/59/Reformirovanie_sistemi_TKO_prezentacia.pdf. 
However, the reform of the MSW management system that began in 2019 in Russia, changes in the conditions for their disposal, the emergence of new technologies for sorting and recycling garbage, the appearance of new garbage trucks, increased requirements for the environmental safety of landfills and disposal of MSW, and a number of other factors showed the need for adjustments to the territorial scheme, taking into account new conditions and factors.

\section{Discussion}

As was already noted, three methods of MSW disposal are used in the world: Landfills, incineration, and recycling. Landfills are widely used in Russia. The method of waste burning has been shown to be ineffective and highly toxic to the air and the environment, which is why there are now no more than 10 such plants in Russia. As a result, the countries which started to use this method in the second half of the twentieth century are gradually abandoning it, and waste-burning plants are closing down.

According to calculations carried out in 2008 by Cleandex (http://www.cleandex.ru/articles/2008/ 03/18/processing_consumer_waste23), the environmental load from incineration plants is much higher than from landfills and recycling plants (Table 4). Thus, we have chosen in the research the option of combining recycling plants and landfills in those areas; garbage removal from these is not economically feasible. The choice of recycling plants corresponds to the prevailing waste management policy in Russia, where, according to the data for 2017, there were 243 waste recycling plants, 50 waste sorting complexes in the plants, and only 10 incinerators (https://musorish.ru/musoropererabatyvayuschiezavody-v-rossii/).

Table 4. Comparison of environmental indicators from incineration, landfills, and recycling.

\begin{tabular}{cccc}
\hline Relative index (in points) of negative impact on: & Incineration & Landfill & Recycling \\
\hline Atmospheric air & 4 & 2 & 1 \\
Aquatic environment & 1 & 3 & 1 \\
Soils & 2 & 3 & 0 \\
Vegetation & 4 & 1 & 0 \\
Public health & 4 & 2 & 1 \\
Complex assessment & Strong & Middle & Near to zero \\
\hline
\end{tabular}

Source: Compiled by the authors.

Gradually, the method of MSW recycling based on preliminary sorting is becoming more and more prevalent. It was this method of waste disposal that was chosen as the main one for improving the territorial scheme of waste management based on the concept of circular economy.

Long-term plans for the development and modernization of the MSW disposal system in the Perm region are focused on the disposal method and on the recycling of waste that can be recycled.

For this purpose, a separate collection of MSW has been organized in the Perm region based on the use of the containerized method for collecting waste. Since 2017, a system of separate collection of solid waste which uses three containers has been operating in the Perm region: 1) A mixture of secondary raw materials (polymers, metals), 2) a mixture of waste paper, and 3) other waste. The main distinguished materials when sorting MSW are plastic, waste paper, metal, and glass.

In addition, 682 autonomous collection points for secondary raw materials are located in the territory of the region. They are located in the territories of large settlements: Perm (645 receiving stations), Krasnokamsk district (15 receiving stations), Berezniki (14 receiving stations), Solikamsk (three receiving stations), and Tchaikovsky district (five receiving stations). However, this is not enough to organize a complete system for the separate collection of MSW and secondary raw materials.

Currently, as a result of the organization of separate collection of MSW and semi-raw materials from the population and infrastructure, the following types of waste are recycling. Table 5 shows the basic information about the types of waste and secondary raw materials processed in the Perm region, 
as well as the potential volumes of their recycling and the size of the profits of waste recycling plants from the sale of processed products.

Table 5. Potential volumes of solid domestic waste recycling and selling price of processed products.

\begin{tabular}{|c|c|c|c|}
\hline $\begin{array}{l}\text { Separately Collected } \\
\text { Feedstock and Recycled } \\
\text { Semi-Raw Materials }\end{array}$ & $\begin{array}{c}\text { The Volume of } \\
\text { Recycling Per Year, Tons }\end{array}$ & $\begin{array}{c}\text { Recycling } \\
\text { Semi-Products }\end{array}$ & $\begin{array}{l}\text { Selling Price Of } \\
\text { Processed Semi-Raw } \\
\text { Materials, \$ Per Ton }\end{array}$ \\
\hline Rubber, caoutchouc & 550 & Rubber crumb & 296.90 \\
\hline Glass & 2145 & Crushed glass & 140.60 \\
\hline Ferrous metals & 1500 & Ferrous scrap & 140.60 \\
\hline Non-ferrous metals & 700 & Non-ferrous scrap & 1406.30 \\
\hline Wood & 1045 & Wood chips & 46.90 \\
\hline Waste paper & 15,400 & Waste paper & 132.80 \\
\hline Textile & 2750 & Rags, fibers & 132.80 \\
\hline Plastic & 2860 & Extruded plastic pellets & 468.80 \\
\hline Other & 11,500 & Incineration & $\begin{array}{l}\text { Average selling price of } \\
\text { electricity generated by } \\
\text { incineration-0.063 } \$ / \mathrm{kVt}\end{array}$ \\
\hline
\end{tabular}

Source: compiled by the authors.

Since the Perm region already operates a waste recycling plant in addition to waste sorting stations, the fractional structure of solid waste is known on average, which allows the forecasting of the volumes of certain types of solid waste sent for recycling (glass, metals, paper and wood, textiles, rubber, etc.). The prices for the final products of recycling given in the corresponding lines of Table 5 are obtained as follows. The costs of final recycling products, which the waste recycling plant sells to consumers, are given as the averages of the market prices for these products in 2019. The price range for crushed glass processed at Russian plants is from 35 to 70 rubles per kilogram (prices from the price list of the company Uralstek (Chelyabinsk)(https://ural.blizko.ru/products/107210269-steklyannaya_kroshka), which amounts to $\$ 546.8-\$ 1093.8$ per ton. The price is standard for Russia and is set at recycling plants already operating in Russia. This is the price of glass granules (crushed glass) already processed at the factory, and not glass containers, including sorted glass containers. Table 5 shows the minimum price $-\$ 546.8$ per ton. Similar prices are offered to Russian consumers by the world's largest company from the Netherlands, which is engaged in the sale of recycled products(https://www.amazon.com/dp/).

In total, according to preliminary calculations, 26,950 tons of various wastes and recyclables can be processed. The total income from the sale of recycled waste per year is about $\$ 5,460,390.63$. Furthermore, the recycling of waste and recyclables is the most promising and cost-effective in comparison with other methods of MSW disposal.

However, an increase in the volume of waste recycling requires an expansion of the methods for separate collection and sorting of MSW.

The development of the new waste management scheme was carried out taking into account the following economic, geographical, and demographic factors:

- $\quad$ Population density in different territories of Perm Krai;

- $\quad$ the total population in separate settlements;

- $\quad$ distance between settlements (length of transportation);

- $\quad$ transport accessibility of settlements (some settlements in the North of the region can be reached only in summer and winter-by rivers);

- quality of roads (even if there are roads, many of them do not have asphalt or hard gravel coating, which makes them impossible to access with garbage trucks);

- $\quad$ costs for construction of one waste recycling plant, for construction of a modern landfill for waste disposal, costs for garbage containers of different types and for construction of container sites for these containers, and costs for construction of waste-sorting stations; 
- $\quad$ volumes of household waste produced by the population;

- the cost of sorting and recycling of one ton of garbage of different types.

In the process of transport logistics modeling, universal logistic models were used. This includes an important element of the model: The method of collecting individual fractions of solid waste. In particular, the possibilities of specific municipalities and households to organize the primary sorting of garbage into various containers at container sites were taken into account. In cases where it is impossible to organize such a collection in the current conditions and in the near future, the model was based on the method of collection of mixed MSW and its subsequent sorting at waste sorting stations. To build the model, modern approaches to the logistics of the output of individual solid waste elements were taken into account using the method of Bing, Keizer, Bloemhof-Ruwaard, and Vorst [19].

The first involves the widespread introduction of containers for separate collection of garbage. The second method requires the construction of sorting stations. Studying the experience of operating waste sorting plants showed that the construction of waste-sorting stations is economically and logistically feasible in territories with a radius of garbage transportation of up to $25 \mathrm{~km}$ and with a volume of solid waste generation of more than 25 thousand tons per year.

Furthermore, the research was adapted to the territorial scheme for MSW management in the Perm region by taking into account the main parameters for the creation of a modern waste management system. The authors built a transport and logistics scheme for the transportation of solid waste by garbage trucks of various classes (from small garbage trucks to large container garbage trucks) based on the calculation of the potential volumes of MSW production by the population and infrastructure facilities of the Perm Territory, taking into account the structure of settlements in the Perm Territory, as well as the transport accessibility of the settlements of the region to the central settlements of their regions (distance in kilometers to the district administrative center) and the availability of transport links between the points (the actual availability of roads).

In the general scheme of recycling of solid waste, the largest investment costs are connected with the construction and operation of waste recycling plants. Therefore, the main part of the study was the calculation to determine the number of such plants needed for the Perm region, as well as the determination of the location for the construction of these plants. The project capacity characteristics of the 2016 Territorial Waste Management Scheme were taken as the basis for calculations of waste recycling complexes. The project calculations are presented in Table 6.

An analysis of the transport and logistics scheme for the distribution of settlements across the territory of the Perm region and their classification as specific areas for the placement of waste recycling complexes showed the presence of very long transport hauls that significantly exceeded normal transportation values.

The results of the research showed that the most optimal for the conditions of the Perm region is the construction of seven new plants with a volume of waste recycling of about 220,000 cubic meters per year. The construction of larger plants is impractical due to the rise in the cost of transportation of MSW. The construction of smaller plants is impractical due to significant investment costs (equipment costs, obtaining a license, maintaining a landfill for solid waste recycling, etc.). Each such plant will serve about 200,000 people and 2000 companies.

The most favorable situation from the point of view of transport accessibility has developed in the city of Perm and the Perm region (object 1) - the shortest transport routes are observed here. Furthermore, this facility accounts for the largest amount of waste, since it covers the territory with the largest population (about 1.2 million people).

The second largest object in terms of waste production and population is the facility located in Berezniki (object 1). The total length of transportation here is greater than in Perm, but the volume of transported waste makes it possible to compensate for the large lengths of the roads. Lysva and Kungur (objects 5 and 6) have almost the same population. The length of roads in these areas is large and it is recommended to use the ring method of collecting MSW with the placement of storage stations. 
Table 6. Waste disposal facility—WRC of Perm city and Perm District.

\begin{tabular}{|c|c|c|c|c|c|}
\hline $\begin{array}{l}\text { Waste disposal } \\
\text { facility-WRC }\end{array}$ & Coverage area & $\begin{array}{l}\text { Administrative } \\
\text { center }\end{array}$ & Distance to WRC, $\mathrm{km}$ & Population & $\begin{array}{c}\text { MSW, tons per } \\
\text { year }\end{array}$ \\
\hline \multirow{3}{*}{ Perm (WRC 1) } & Dobryansky district & Dobryanka city & 73.3 & 55,578 & $13,894.5$ \\
\hline & Ilyinsky District & Settlement Ilyinsky & 91.4 & 18,542 & 4635.5 \\
\hline & $\begin{array}{l}\text { City district ZATO } \\
\text { "Zvezdny" }\end{array}$ & $\begin{array}{l}\text { Urban village } \\
\text { "Zvezdny" }\end{array}$ & 36.0 & 5376 & 1344 \\
\hline \multirow{5}{*}{ Berezniki (WRC 2) } & Perm city district & Perm city & 0 & $1,053,938$ & $263,484.5$ \\
\hline & Kizelovsky district & Kizel city & 82.3 & 18,765 & 4691.25 \\
\hline & Krasnovishersky district & $\begin{array}{l}\text { Krasnovishersk } \\
\text { city }\end{array}$ & 128.3 & 19,749 & 4937.25 \\
\hline & Solikamsk district & Solikamsk city & 32.7 & 16,019 & 4004.75 \\
\hline & Usolsky district & Usolye city & 11.3 & 50,620 & 12,655 \\
\hline \multirow{11}{*}{ Nytva (WRC3) } & Bolshesosnovsky district & $\begin{array}{l}\text { Village Bolshaya } \\
\text { Sosnova }\end{array}$ & 74.0 & 12,282 & 3070.5 \\
\hline & Vereshchaginsky district & Vereshchagino city & 73.0 & 39,180 & 9795 \\
\hline & Gain district & Settlement Gainy & 297.5 & 11,783 & 2945.75 \\
\hline & Karagaysky district & Village Karagay & 51.1 & 21,228 & 5307 \\
\hline & Krasnokamsky district & Krasnokamsk City & 37.4 & 27,467 & 6866.75 \\
\hline & Nytvensky district & Nytva City & 0 & 41,156 & 10,289 \\
\hline & Yusvensky district & Village Yusva & 150.4 & 17,142 & 4285.5 \\
\hline & Kudymkar district & Kudymkar City & 138.1 & 22,319 & 5579.75 \\
\hline & Ohansky district & Okhansk City & 63.0 & 15,970 & 3992.5 \\
\hline & Ochersky district & Ocher City & 52.8 & 22,678 & 5669.5 \\
\hline & Sivinsky district & Village Siva & 91.1 & 13,662 & 3415.5 \\
\hline \multirow{3}{*}{$\begin{array}{l}\text { Chaikovsky } \\
\text { (WRC4) }\end{array}$} & Osinsky district & Osa city & 132.6 & 28,278 & 7069.5 \\
\hline & Chaikovsky district & Chaikovsky city & 0 & 104,306 & $26,076.5$ \\
\hline & Chernushinsky district & Chernushka city & 152.4 & 50,408 & 12,602 \\
\hline \multicolumn{4}{|c|}{ Total population and municipal solid waste } & 240,945 & $60,236.25$ \\
\hline \multirow{6}{*}{ Kungur (WRC 5) } & Berezovsky district & Village Berezovka & 33.1 & 22,246 & 5561.5 \\
\hline & Kishert district & Village Ust-Kishert & 40.8 & 11,361 & 2840.25 \\
\hline & Kungursky district & Kungur city & 0 & 41,652 & 10,413 \\
\hline & Kungur city district & Kungur city & 0 & 65,284 & 16,321 \\
\hline & Orda district & Village Orda & 33.9 & 36,045 & 9011.25 \\
\hline & Suksun district & $\begin{array}{l}\text { Village type } \\
\text { Suksun }\end{array}$ & 54.2 & 19,181 & 4795.25 \\
\hline \multirow{10}{*}{ Lysva (WRC 6) } & Yinsky district & Village Uinskoye & 96.5 & 10,292 & 2573 \\
\hline & Oktyabrsky District & $\begin{array}{l}\text { The working } \\
\text { village Oktyabrsky }\end{array}$ & 120.0 & 27,139 & 6784.75 \\
\hline & \multicolumn{2}{|c|}{ Total population and municipal solid waste } & & 233,200 & 58,300 \\
\hline & Gornozavodsky district & Gornozavodsk city & 65.3 & 23,262 & 5815.5 \\
\hline & Gremyachinsky district & Gremyachinsk city & 60.9 & 10,599 & 2649.75 \\
\hline & Chusovskoy district & Chusovoy city & 20.9 & 66,381 & $16,595.25$ \\
\hline & Lysvensky urban district & Lysva city & 0 & 71,772 & 17,943 \\
\hline & $\begin{array}{l}\text { Gubakhinsky urban } \\
\text { district }\end{array}$ & Gubakha city & 97.5 & 33,374 & 8343.5 \\
\hline & Total population and $n$ & anicipal solid waste & & 205,388 & 51,347 \\
\hline & al population and municip & solid waste in Perm $r$ & gion & $2,688,546$ & $672,136.5$ \\
\hline
\end{tabular}

* Note: WRC-waste recycling complex. Source: Compiled by the authors.

The most difficult is the Tchaikovsky cluster due to the length of the distances for the transportation of MSW (object 4). However, the settlements there are located in such a way that one can go "in a circle" to reach all the necessary points. In addition, it is proposed to allocate a special zone in the city of Barda with the construction of a waste recycling complex, which serves the settlements of the south-west of the Perm region (including the cities of Chernushka and Kueda). 
The Nytva cluster is the most controversial one (object 3 ). There is currently a landfill for waste disposal in Krasnokamsk on its territory. This is a fairly modern complex, which is used for sorting and recycling a number of wastes. This waste is delivered to this landfill, including from the city of Perm.

At the same time, there are many cases like the village of Gayny (the distance to which is almost $300 \mathrm{~km}$ ), the Kosinsky district (the distance to Nytva is $285.6 \mathrm{~km}$ ), the Kochevsky district (the distance to Nytva is $214.8 \mathrm{~km}$ ), and a number of other remote areas with a small number, which are included in the Nytva cluster population and have small amounts of accumulated garbage.

In this case, it is necessary to create a number of intermediate storage and sorting stations, which can reduce the "shuttle" distances for garbage transportation and reduce transportation costs. Such intermediate stations will ensure the storage and accumulation of the fractions of MSW that can be stored for a long time without causing damage to the environment or losing the quality characteristics of the stored waste itself. This includes such waste as plastic, glass, metal cans and other metal products, waste paper, wood, textiles, etc. These wastes and secondary raw materials can be transported by special machines once a month or even less. In this case, food waste after cleaning should immediately go to compost. The remaining types of MSW can be transported by special machines to landfills for their disposal 1-2 times per week (or more often, or less often) depending on the rate of waste accumulation.

So, in the Nytva cluster (facility 3), it is proposed to maintain and modernize the landfill in the city of Kudymkar and create a sorting station there; the treated waste can be in larger quantities and be less frequently transported to a waste recycling plant in the city of Nytva. In addition, the administration of the Perm region proposes to start an experimental plant in the village of Barda.

At the same time, 28 transshipment stations will be created. First, the garbage will be collected at a transfer station, then in press containers on special vehicles to landfills.

Thus, we propose the following layout of marshaling yards, waste recycling stations, waste recycling plants, and landfills for the disposal of non-recyclable waste. The scheme is shown in Figure 4. As for the economic efficiency of the new waste recycling plants, the calculations showed the following. Construction of the plant and its launch is carried out within one year. The territory of the waste treatment plant together with sanitary zone is 50,000 square meters. For the project of construction of a waste recycling plant, an investment of $\$ 195$ million rubles ( $\$ 3$ million) is required, including: costs for acquisition and installation of equipment- 96 million rubles (1.5 million USD), the construction-95.5 million rubles (1.5 million USD), licenses- 1.5 million rubles (23.4 thousand USD), and for others about 2 million rubles. (31.3 thousand USD).

The main financial indicators of operation of the waste recycling plant in 10 years after the beginning of operation:

- $\quad$ Investments-3 million USD;

- $\quad$ total revenue with VAT-2,977.4 million rubles—46.5 million USD;

- $\quad$ the costs of current activity-1,644.7 million rubles-25.7 million USD;

- $\quad$ balance from core business-1,332.7 million rubles-20.8 million USD;

- $\quad$ net profit of the project-1,241.5 million rubles-19.3 million USD;

- $\quad$ assets on the balance sheet at the end of the planning period-93.3 million rubles-1.5 million USD.

The main indicators for the project efficiency are the following:

- $\quad$ Net Present Value - 629.1 million rubles-9.8 million USD;

- $\quad$ Break-even point - 16.1 million rubles-0.25 million USD;

- $\quad$ Period of Investments - 4.2;

- Internal Rate of Return $-66.9 \%$;

- Payback period (discounted) - 2.5 years.

It is expected to achieve such indicators for each of the newly built waste recycling plants. Construction and operation of plants is supposed on the basis of private-public partnership, which 
provides the greatest efficiency for the solution of large tasks within administrative-territorial structures, as is explained in the research of Mingaleva, Pazdnikova, and Mitrofanova [20].

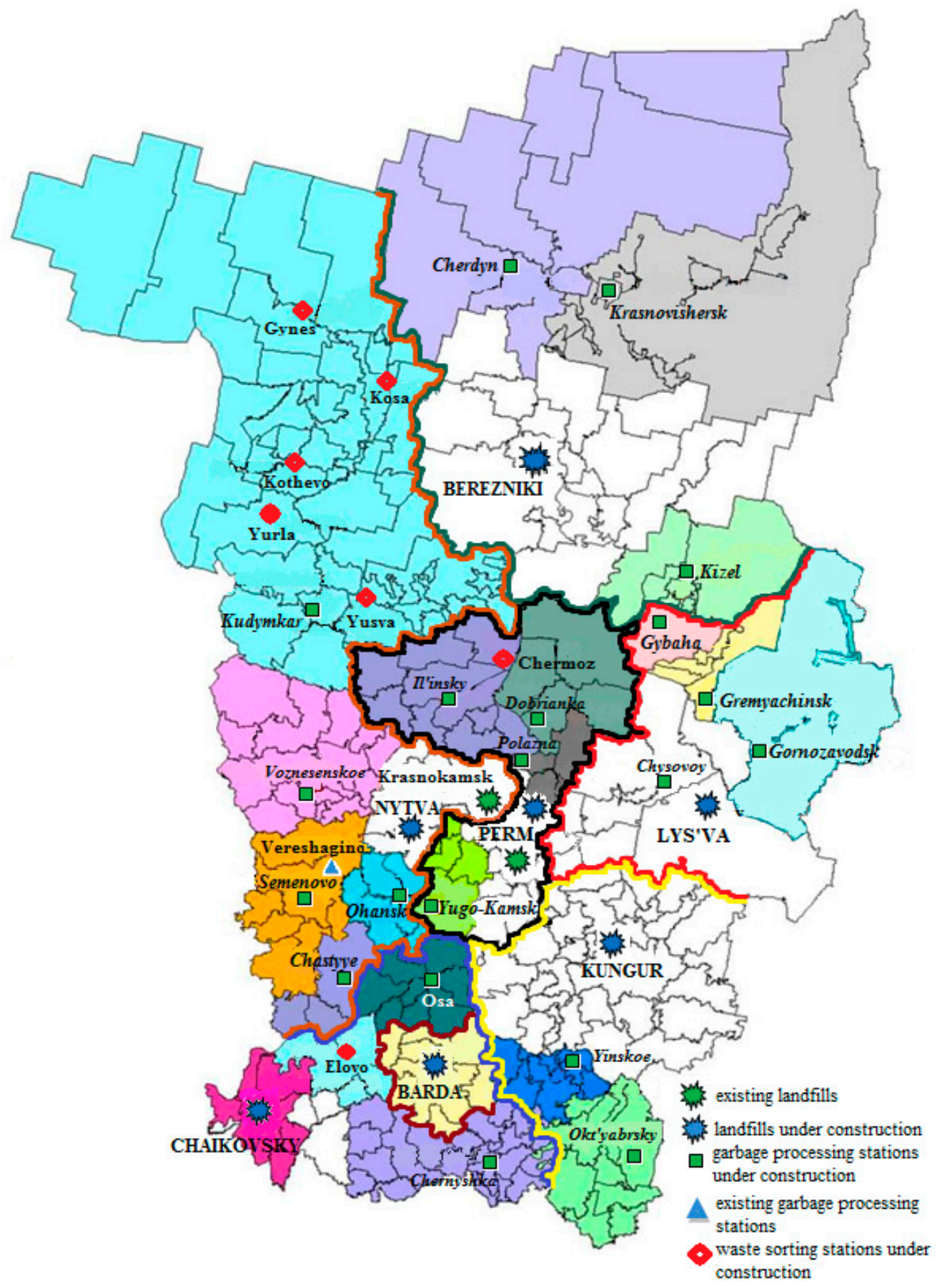

Figure 4. A promising scheme for creating an environmentally friendly waste management system, taking into account the requirements for creating a green economy. Source: https:/investinfra.ru/frontend/ images/RO/59/Reformirovanie_sistemi_TKO_prezentacia.pdf.

As we mentioned in the theoretical section, the role of active and smart citizens in the development of green and smart cities is very important (Demirović, Radovanović, Petrović, Cimbaljević, Vuksanović, Vuković, Larionova, etc. (2018), Wang, Kintrea (2019)) [21-23]. Furthermore, their influence on urban development is stronger in the case of the agglomeration process, especially in small provincial urban centers (Vuković, Larionova, Platonov, and Vuković (2017)) [22]. 
The proposed solid domestic waste management scheme will significantly improve the waste management mechanism in the Perm District and the city of Perm, and will fully implement the concept of circular economy as part of the implementation of the green city program in Perm.

\section{Conclusion}

Waste management is an important element of modern sustainable concepts of smart and green cities. The development of waste management consists of two main connected parts:

- Technological development and

- $\quad$ social and cultural development.

They are closely connected and influence each other. For countries with sparse populations and large territories, waste management has specific characteristics, which are mainly determined by waste logistics. The methods used for waste collection directly depend on the specific method of waste disposal. A competent combination of these methods allows for a high degree of coverage of MSW collection, which reaches $98 \%$ in large cities of the regions.

In accordance with the adapted transport and logistics scheme for the transportation of MSW in the Russian case study of Perm, it was determined that waste-sorting stations should be located as part of the so-called waste recycling complexes at municipal landfills. This will allow more full implementation of the concept of recycling production not only in the city of Perm, but also in neighboring districts.

Further technological prospects for studying the transition of modern cities to the concept of a green city suggest further research in the area of recycling economy through a deeper detailing of the process of creating a system for the complete utilization of waste produced by the population and enterprises of the city.

At the same time, it is important to develop networking of smart citizens-as indicated in Table 2-because citizens influence the development of more than $60 \%$ of urban smart technologies. The effectiveness of introducing green technologies and ensuring the sustainable development of modern cities, especially in waste management, depends on the level of participation of citizens. People are active participants in the life processes of cities and have a direct impact on the urban environment; the introduction of green technologies can only be achieved in harmony with the well-established behavioral attitudes of city residents together with the implementation of green and smart urban technologies.

Author Contributions: Conceptualization, formal analysis: Z.M.; methodology and funding acquisition: N.V.; investigation, data curation: I.V.; resources, software: T.S. All authors have read and agreed to the published version of the manuscript.

Funding: The work is carried out based on the task on fulfillment of government contractual work in the field of scientific activities as a part of base portion of the state task of the Ministry of Education and Science of the Russian Federation to Perm National Research Polytechnic University (the topic \# 26.6884.2017/8.9 "Sustainable development of urban areas and the improvement of the human environment") (Mingaleva, Zh., conceptualization, formal analysis).

Acknowledgments: This publication has been prepared with the support of the "RUDN University Program 5-100" (Vukovic, N., methodology).

Conflicts of Interest: The authors declare no conflict of interest.

\section{References}

1. Burkart, K. How do you define the green economy. Mother Nat. Netw. 2009.

2. Vukovic, N.; Pobedinsky, V.; Mityagin, S.; Drozhzhin, A.; Mingaleva, Z. A Study on Green Economy Indicators and Modeling: Russian Context. Sustainability 2019, 11, 4629. [CrossRef]

3. Eydenzon, D.V.; Ganieva, I.A.; Shpak, N.A. Socio-economic and environmental aspects of the industry imbalances in the regional economy. Reg. Econ. 2013, 4, 115-122. [CrossRef] 
4. De Jong, M.; Joss, S.; Schraven, D.; Zhan, C.; Weijnen, M. Sustainable-smart-resilient-low carbon-eco-knowledge cities; making sense of a multitude of concepts promoting sustainable urbanization. J. Cleaner Product. 2015, 109, 25-38.

5. Soumya, P.; Alok, G. Effective approach towards elegant, smart and green city. Int. J. Civ. Eng. Technol. 2018, 9, 2164-2169.

6. Polzonetti, A.; Sagratella, M. Smart City and Green Development. In Conference on e-Business, e-Services and e-Society; Springer: Cham, Switzerland, 2018; pp. 191-204.

7. Donnellan, B.; Klein, C.; Helfert, M.; Gusikhin, O.; Pascoal, A. (Eds.) Smart Cities, Green Technologies, and Intelligent Transport Systems. In 6th International Conference, SMARTGREENS 2017, and Third International Conference, VEHITS 2017, Porto, Portugal, 22-24 April 2017, Revised Selected Papers; Springer: Berlin, Germany, 2018; Volume 921.

8. Camboim, G.F.; Zawislak, P.A.; Pufal, N.A. Driving elements to make cities smarter: Evidences from European projects. Technol. Forecast. Soc. Change. 2019, 142, 154-167. [CrossRef]

9. Brilhante, O.; Klaas, J. Green City Concept and a Method to Measure Green City Performance over Time Applied to Fifty Cities Globally: Influence of GDP, Population Size and Energy Efficiency. Sustainability 2018, 10, 2031. [CrossRef]

10. Morero, B.; Montagna, A.F.; Campanella, E.A.; Cafaro, D.C. Optimal process design for integrated municipal waste management with energy recovery in Argentina. Renew. Energy 2020, 146, 2626-2636. [CrossRef]

11. Shumal, M.; Jahromi, A.R.T.; Ferdowsi, A.; Dehkordi, S.M.M.N.; Moloudian, A.; Dehnavi, A. Comprehensive analysis of municipal solid waste rejected fractions as a source of Refused Derived Fuel in developing countries (case study of Isfahan-Iran): Environmental Impact and sustainable development. Renew. Energy 2020, 146, 404-413. [CrossRef]

12. Lou, C.X.; Shuai, J.; Luo, L.; Li, H. Optimal transportation planning of classified domestic garbage based on map distance. J. Environ. Manag. 2020, 254, 109781. [CrossRef] [PubMed]

13. Vukovic, N.; Rzhavtsev, A.; Shmyrev, V. Smart city: The case study of Saint-Petersburg 2019. Int. Rev. 2019, $1-2,15$.

14. Mingaleva, Z.; Shpak, N. Possibilities of solar energy application in Russian cities. Science 2015, 19, 457-466. [CrossRef]

15. Salimova, T.A.; Gouskova, N.D.; Fedoskina, L.; Gorin, I.A. Competitiveness, Sustainable Development and Import Substitution Problems in the Russian Federation. J. Appl. Econ. Sci. 2017, 12, 4.

16. Slanina, Z.; Pokorny, R.; Dedek, J. Waste Management-Weighing-Machine Automation. In AETA 2018: AETA 2018-Recent Advances in Electrical Engineering and Related Sciences: Theory and Application, Proceedings of the International Conference on Advanced Engineering Theory and Applications, Ostrava, Czech Republic, 11-13 September 2018; Springer: Cham, Switzerland, 2018; pp. 747-757.

17. Tirkolaee, E.B.; Mahdavi, I.; Esfahani, M.M.S.; Weber, G.W. A robust green location-allocation-inventory problem to design an urban waste management system under uncertainty. Waste Manag. 2020, 102, 340-350. [CrossRef] [PubMed]

18. Weidner, T.; Yang, A. The potential of urban agriculture in combination with organic waste valorization: Assessment of resource flows and emissions for two European cities. J. Clean. Prod. 2020, 244, 118490. [CrossRef]

19. Bing, X.; de Keizer, M.; Bloemhof-Ruwaard, J.M.; van der Vorst, J.G. Vehicle routing for the eco-efficient collection of household plastic waste. Waste Manag. 2014, 34, 719-729. [CrossRef]

20. Mingaleva, Z.; Pazdnikova, N.; Mitrofanova, E.A. The development of the concession project management mechanisms in regions. Asian Soc. Sci. 2014, 10, 257-262. [CrossRef]

21. Demirović, D.; Radovanović, M.; Petrović, M.D.; Cimbaljević, M.; Vuksanović, N.; Vuković, D.B. Environmental and community stability of a mountain destination: An analysis of residents' perception. Sustainability 2018, 10, 70. [CrossRef]

22. Vuković, D.B.; Larionova, V.A.; Platonov, A.M.; Vuković, N.A. Does agglomeration process exist in small provincial urban centers? Evidence from Sverdlovsk region. J. Geogr. Inst. Cvijic'sasa 2017, 67, 3.

23. Wang, Y.P.; Kintrea, K. Sustainable, Healthy and Learning Cities and Neighbourhoods. Environ. Urban. Asia 2019, 10, 146-150. [CrossRef] 
(C) 2019 by the authors. Licensee MDPI, Basel, Switzerland. This article is an open access article distributed under the terms and conditions of the Creative Commons Attribution (CC BY) license (http://creativecommons.org/licenses/by/4.0/). 